treatment. Naturally, because replacements are not allowed in a match below representative grade, the team doctor is expected to apply a hasty second-aid Elastoplast strapping and even a local anaesthetic to mask the agony. Admittedly, the player reappears of his own free will, but he knows well that if he does not, his team mates must battle on, with one position unfilled. His courage gets the better of his common sense, and the situation impedes the giving or accepting of sound medical judgement. Many doctors associated with clubs and teams throughout the whole rugby world must be familiar with cases of players who aggravate an injury by resuming exercise too soon and thus, ensure for themselves a long painful lay-off. It is well recognized that all this is further bedevilled by the all-round increase in fixtures and player engagement, which rarely leaves more than a couple of days to shake off the effects of even trivial trauma. Replacements will be more widely accepted in the future. Doctors and consultants, who are close to the problem, could hasten the day by using their influence in the corridors of rugby power.-I am, etc.,

FREDERICK C. DWYER,

Plymouth

Devon Rugby Football Union

\section{Bacteroides Infections}

SIR,-In your epidemiological notes (17 March, p. 686) reference is made to reports gathered by the Public Health Laboratory Service of the isolation by blood culture of species of Bacteroides from 76 patients during the last $9 \frac{1}{2}$ months of 1972 . This is the greatest concentration of such infections yet reported in the United Kingdom and the Irish Republic and it follows other recent accounts, such as that of six patients treated in Glasgow in 1972.1

Between 1933 and 1944 I isolated organisms of the genus Bacteroides from 12 patients in hospitals in North London, and records of these were published in 1955, with an analysis of 268 other cases in the literature from eight countries. From 1944 to 1965 no new example of the infection was found in the same hospitals, although looked for. The organisms are known to be common saprophytes of the human gastrointestinal tract and are relatively easily cultivated. From my own experience I think that the variation in the reported incidence of infection is more probably due to altered opportunities for the invasion of the tissues than to varying attention of bacteriologists to the possibility. The bacteraemia in 1972 "was most commonly reported in elderly patients, most of whom were known to have an underlying illness." In the records of 20 years $\mathrm{ago}^{2}$ the patients were of all ages from childhood onwards and the infection was more often the primary and sole disease in the form of extensive and often multiple suppuration.

The bacteroides are the cause of many lesions in wild and domestic animals and reach human beings by contact and probably by consumption of infected animal tissues. Among the 280 cases which I analysed there were four main groups. One was of infection of the skin or subcutaneous tissues by way of civilian injuries or war wounds, or directly from live animals or their tissues in the case of farm workers and butchers. A second group, the largest, was of infections which started in the throat, after tonsillectomy or with sore throat or otitis media as the first symptom. Thirdly, there were many infections by way of the female genital tract, mostly after abortion or in the puemperium, and fewer, in either sex, by the alimentary tract, sometimes after surgical operation, or by the urinary tract. The fourth group showed empyema, with or without lung abscess, as the first symptom. When lung abscess preceded empyema it was thought that inhalation from the mouth or throat might be the origin.-I am, etc.,

London $\mathbf{W} .1$

J. M. Alston

1 Tracy, O., Gordon, A. M., Moran, F., Love, fourmai, $1972,1,280$.
iston, J. M., British Medical fournal, 1955, 2, 1524.

\section{Zollinger-Ellison Syndrome Reclassified}

SIR,-A number of recent papers in journals without correspondence coloumns have complicated the picture of the Zollinger-Ellison considerably and, despite your excellent leading article (6 January, p. 2), I find certain of my colleagues and most medical students thoroughly confused.

The syndrome to which Zollinger and Ellison gave their name ${ }^{l}$ (though they were not the first to describe cases) had a diagnostic triad of (1) fulminating peptic ulceration (often multiple, recurrent, and atypically situated), (2) gigantic gastric acid secretion, and (3) non-insulin-secreting islet cell tumours of the pancreas. It was subsequently recognized that the tumours could occur in ectopic pancreatic tissue, ${ }^{2}$ the substance they secreted was identified as gastrin, ${ }^{34}$ and eventually the secretory cells were shown to be $\mathrm{D}$ cells. ${ }^{5}$ The picture thus far is clear.

Unfortunately it was soon shown that the clinical features of the syndrome could be caused by mere hypertrophy of the pancreatic islets, ${ }^{2}$ and more recently Polak and her colleagues showed that profound antral $G$ cell (that is, gastrin-secreting cell ${ }^{6}$ ) hyperplasia could produce a similar picture. ${ }^{7}$ The latter divided patients into a group with hyperplasia or frank tumour in the pancreatic islets and a group with $G$ cell hyperplasia and a normal pancreas. Last year, resection of a gastric tumour containing gastrin and appearing to arise from antral $G$ cells from a case of "clinical" Zollinger-Ellison syndrome was reported. 8

Diarrhoea was described early in certain cases of the Zollinger-Ellison syndrome ${ }^{1}$ and has been variously attributed to hypersecretion by the small intestine, dure to the direct action of excess acid;9 increased secretion of pancreatic enzymes; ${ }^{2}$ and steatorrhoea, which undoubtedly occurs in many cases and is almost certainly due to irreversible inactivation of pancreatic lipase by the low jejunal $\mathrm{pH}$, though dilution of bile acids and precipitation of glycine dihydroxyconjugated bile acids may play a part.10 A few cases have obvious causative anatomical lesions. ${ }^{2}$ Two patients with intractable diarrhoea associated with non- $\beta$ cell islet cell tumours of the pancreas were described in 1958 by Verner and Morrison"1 and further examples were discussed by
Telling and Smiddy, ${ }^{12}$ who suggested that they were dealing with a situation different from classical Zollinger-Ellison syndrome. Howe $^{2}$ described more cases and even documented the lack of associated gastric hypersecretion (achlorhydria in many) and peptic ulceration, but merely classified them as a variant of the Zollinger-Ellison syndrome. I have found that certain of my colleagues still hold to this view. I, however, would agree with your leading article that these cases should be classified as a completely separate entity, since the only feature they have in common with "proper" cases of the Zollinger-Ellison syndrome is non $\beta$ cell tumours of the pancreas, which do not even secrete gastrin (it has been suggested that they produce gastric inhibitory polypeptide ${ }^{13}$ ), and some have been reported to respond to steroids, ${ }^{9}$ which are no use in "proper" cases. The suggested name of W.D.H.W. syndrome9 seems to me as good as any, especially as the letters remind one of the cardinal features of the condition.

I should like to put forward a tentative classification of the spectrum of ZollingerEllison syndrome cases encountered. As the syndrome which Zollinger and Ellison actually documented included pancreatic lesions I suggest that cases of D cell hyperplasia be termed type I Z-E syndrome and those with tumours, whether in pancreas proper or ectopic pancreatic tissue, be termed type II. The cases with gastric lesions could conveniently be termed pseudo-Z-E syndrome type I ( $G$ cell hyperplasia) and type II (tumour of $G$ cells). Cases with the clinical features of classical ZollingerEllison syndrome and undefined pathology would remain unclassifiable.

It is to my mind important to attempt some sort of classification in view of the different treatments applicable to the different types (for example, vagotomy and antrectomy for pseudo-Z-E syndrome type $\left.I^{13}\right)$. I should be interested to see readers' comments.-I am, etc.

\section{ELIZABETH STEPHENS}

Gastrointestinal Laboratory

St. Thomas's Hospital

1 Zollinger, R. M., and Ellison, E. H., Annals of 2 Howe, C. T., Scottish Medical Journal, 1965, 10 307.

3 Gregory, R. A., Grossman, M. I., Tracy, H. J., 4 McGuigan, J. E., and Trudeau, iw. IL., New Enland Fournal of Medicine, 1968, 278, 1308. 1971, 20, 389 .

Bussolati, G., and Pearse, A. G. E., Histochemie, 1970, 21, 1 .

Gut, 1972, 13, 501 , B., and Pearse, A. G. E.

8 Cowley, D. J., et al., Gut, 1973, 14, 25. . H., Marks, I. N., Bank, S., and

Go, V. L. W. W., Poley, J.' R., Hofmann, A. F., and
Summerskill, w. H. J., Gastroenterology, 1970, 58,638 .

11 Verner, J. V. and Morrison, A. B., American Fournal of Medicine, 1958, 25, 374. 12 Telling, M.. and Smiddy, F. G., Gut, 1961, 2, 12.

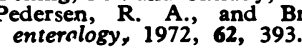

\section{Results of Renal Transplantation}

SIR,-We are grateful to Dr. S. C. Farrow and his colleagues (31 March, p. 800) for pointing out an error in our results. One of the patients who rejected was in fact omitted in error from the published actuarial survival curve. In addition, one of our patients rejected at the end of 12 months and Dr. 